\title{
Socialisation and Recruitment in Islamist Movements: A Comparison between the Muslim Brotherhood and Al-Qaeda
}

\author{
SIVAMURUGAN PANDIAN*, OMAR GOMAA \& NUR HAFEEZA AHMAD PAZIL ${ }^{1}$
}

\begin{abstract}
To date, a little work has been undertaken to compare the socialisation process between the Muslim Brotherhood and Al-Qaeda. According to critics, both are considered intermediate and extremist movements. While the Muslim Brotherhood utilises various methods of socialisation, Al-Qaeda utilises internet networks to recruit new members without looking at their prior history, leaving the Al-Qaeda movement extremely vulnerable. This article explores the main differences in the roles and impacts of the political movements the Muslim Brotherhood and Al-Qaeda. It focuses on the most significant aspect of the socialisation process on shaping alfard al-muslim the individual Muslim.
\end{abstract}

Keywords: Islamism, Muslim Brotherhood, Al-Qaeda, recruitment, socialisation

The Muslim Brotherhood is the most influential Islamist movement in the world (Hoffman 1995). An Arabic schoolteacher, Hassan Al-Banna, has previously attempted to disseminate the idea of Islamic politics amongst Egyptians. Despite his hardworking efforts, the concept of Islamic politics was abstruse amongst Egyptians for several reasons (Vannetzel 2017). Firstly, Hassan AlBanna initially attempted to disseminate his perspective in his twenty's, which means he lacked experience and knowledge. Secondly, Al-Banna graduated from a public University, Hence, Al Azhar Islamic University criticised his preaches at mosques (Ismail 2010: 50), assuming that he is not knowledgeable enough to spread his Islamic ideas.

Since the emergence of the Muslim Brotherhood hitherto, the movement is seen dissolute, deprived of political rights and exiled from Egypt. The movement have had their personal properties confiscated and have been tortured in incarcerates (Sarmanlou \& Goudarzi 2015). Conclusively, in 2013, the Muslim Brotherhood faced tribulation by the coup committed by the Egyptian military, led by the Minister of Defence Abdel Fattah al-Sisi. Al Sisi has detained thousands of Egyptian youth, women, political elites and clerics to consign Egyptian political arena backwards from the democratic trajectory that had been normatively taken by Egyptians during the 25th of January revolution that toppled the despot Hosni Mubarak (Mokhtar 2017).

Al-Qaeda, a militant Islamic Sunni movement emerged during the Soviet Union war in Afghanistan (Bergen 2006). Al-Qaeda was founded by Arab mujahideen who have been recruited to fight against the Soviet Union. They were denied by their regimes to repatriate, hence they established Al-Qaeda and embraced armed jihadist ideology against the interests of the West alongside the Arabian regimes (Sedgwick 2004).

\footnotetext{
${ }^{1}$ Sivamurugan Pandian* (correspondent author), Ph.D, professor at Department of Anthropology and Sociology, School of Social Sciences, Universiti Sains Malaysia, 11800 PULAU PINANG, Malaysia, email: psiva@usm.my; Omar Gomaa Ahmed Mohamed, MA candidate, Department of Anthropology and Sociology, School of Social Sciences, Universiti Sains Malaysia, 11800 PULAU PINANG, Malaysia, email: omarjomaa2006@gmail.com; Nur Hafeeza Ahmad Pazil, Ph.D., lecturer at Department of Anthropology and Sociology, School of Social Sciences, Universiti Sains Malaysia, 11800 PULAU PINANG, Malaysia, email: hafeezapazil@usm.my.
} 
In 2001, the ascendency of Al-Qaeda took the movement into a point of no return after committing several extremist attacks on America, striking thousands of victims. Since then, the war against extremist Islamic movements took place in the Middle East, particularly Afghanistan and Iraq (Warner \& Hulme 2018).

\section{Socialisation at the Early Age in Muslim Brotherhood and Al-Qaeda}

The adult who knows his role in the political organisation will establish predisposition (Miller \& Shanks 1996). Downs (1957) stated that adults are quite responsive to current political realities; they tend to take role if they believe that their role can make a change. Moreover, many preadolescents also like to express their political opinion (Hess \& Torney 1967), however it is not taken into consideration. Scholars still have not concluded whether preadult opinion will make a difference. Marsh (1971) examined that attaining the level of adult people in regard to expressing political opinion needs a highly stable socialisation and a long process of learning attitudes to be well into adulthood.

Socialisation portrays how people change overtime during their life (Bassis, Gelles \& Levine 1998). Regarding sociological perspective, preadolescents should be identified as wellsocialised if they have good attitudes and understanding toward political processes. However, an experienced opinion by a preadult does not mean that the preadult is completely crystallised (Converse 1979). In both movements, the child starts gaining knowledge of political socialisation during early age. This is exemplified by Hassan Al-Banna teaching his followers and young listeners that Islam is a way of life and each aspect of Islam is embodied in life (Brykczynski 2005).

The Muslim brotherhood are immensely knowledgeable of Islamic teachings; hence allowing them to have an influential stance on political socialisation (Ibrahim \& Alwi 2018). Hassan Al-Banna inveigled young people through his preaches on cafes, cinemas and social clubs (Munson 2001: 488-490). He established a plan to socialise his young cohorts based on special Islamic programmes, as the man's idea was to disseminate the concept of the Muslim Brotherhood in all diameters in Egypt (Aboul-Enein 2003: 27). However, the youth of the Muslim Brotherhood had enough trust in Al-Banna's ideology, and they declared they would die in the sake of Islam (Abdul Halim 1979). Most importantly, the youths were socialised by Al-Banna personally, who inculcated the value of Islamic teachings in his followers to be prepared for an Islamic society that ruled by Islamic rule, which would be the first step of Islamisation. Furthermore, Al-Banna had entrenched a community network, which was supported by the parents of the Muslim Brotherhood, to socialise their children based on Islamic teachings (AboulEnein 2003: 30).

On the other hand, Al-Qaeda train their children at an early age to deploy weapons and receive instructions to manufacture bombs (Singer 2005). Most of Al-Qaeda children are born as members of Al-Qaeda (Singer 2003), Benotman and Malik (2016) stated that the children of extremist Islamist movements are socialised on the love of jihad, and they envisage themselves as martyrs to die in the sake of Allah, to obtain the highest level of Jannah (the living martyr).

Al-Qaeda utilise political socialisation as a method to inculcate the value of Islamic jihad into preadolescents. Therefore, the aftermath of $11^{\text {th }}$ of September attacks led the American intelligence's gaze to turn onto extremist Islamist movements to understand their ideology and their seeking for jihad (Snider 2008). These perpetrators came from different countries and communities (Foda 2005). This left a vague question, what value had been inculcated into the perpetrators minds to suicide themselves?

\section{Socialisation and Recruitment in the Muslim Brotherhood and al-Qaeda}

Socialisation defines people's characteristics and how they predisposed in social groups (Bassis, Gelles \& Levine 1998: 105). Therefore, Hassan Al-Banna pursed to entrench a stalwart nexus of 
members who would have peremptory and obedience towards him (Iman 2005). He also initiated preaching with his peers to coax Egyptians to believe in his Ideology, which is, that Islam and politics are inseparable. Still, Al-Banna implanted the value of Islam in his cohorts. He had chosen his cohorts accordingly to rigorous conditions, ensuring they will be socialised due to Islamic teachings and manhaj "curriculum" taught by him personally (Abdul Halim 1979).

Moreover, in pointing to Islamic socialisation, the Muslim Brotherhood institutions play a significant role in this stage, hence Al-Banna had relied on the four agents of socialisation, which are family, peer groups, schools and mass media (Henslin 1995). Prior to the emergence of the Muslim Brotherhood, Al-Banna had been influenced by his father, who had been a famous Islamic scholar (Kraemer 2010). At the early age of Al-Banna, his father sent him to learn Koran and Islamic teachings in religious schools (Gomaa 2002). However, he graduated from Cairo University, not Al-Azhar, therefore, he was not welcomed to preach inside mosques as Al-Azhar clerics ceased him several times (Al-Qaradawi 1998). Regardless, this didn't stop Al-Banna from pursuing his goal. He believed that the roles of the parents are able to shape an orthodox Muslim, hence he educated the old segments of the movements though private teachings in order for them to socialise their children based on a specific perspective that he believed will enhance the Egyptian society.

In more explanations to the agents of socialisation in the Muslim Brotherhood, schools had influenced the movement within its history; it is the most significant agent of socialisation as school curriculum is specifically designed to socialise- to turn individual children into active members of society who are committed to its culture (Bassis, Gelles \& Levine 1998: 116). Hence, Al-Banna had planned to entrench independent religious schools from the education authorities, where the students can be taught Islamic teachings (Jung \& Sinclair 2020: 90). To be successful, the Muslim Brotherhood movement needed to establish several branches, therefore Hassan AlBanna began construction of mosques, utilising the fund from members who own local trades and business. The movement also began to build a boy's school, girl's school and social clubs to gather youths for several activities (Abdul Halim 1980). They continued to construct more schools, until they had more than one hundred schools by 2013 (Al-Anani 2019). However, in September 2018, the Committee for the Reservation, Stockpiling, Management and Disposal of Terrorist and Terrorist Groups issued a decision to hold 1589 members of the Brotherhood, 118 companies, 1133 NGOs, 104 schools, 69 hospitals and 33 websites and satellite channels claiming that they belong to the banned group and they transferred these assets to the State Treasury. This unprecedented action against the group indicates that the regime of President Abdel Fattah alSisi ultimately decided to dominate the assets of the Muslim Brotherhood, estimated at 300 billion Egyptian pounds, \$ 16.7 billion (Al-Anani 2019).

Moreover, regarding the agents of socialisation in the Muslim Brotherhood, peer groups. Sociologists examined that individuals join reference groups when they are unsure of what to think or do, hence they tend to take role of those movements, where they can evaluate their own performance (Bassis, Gelles \& Levine 1998: 118). Therefore, Hassan Al-Banna, created a coherent relationship amongst his followers by entrenching a complex system, called usrah, where the member of the Muslim Brotherhood has to meet his peers each week at least once to discuss their issues, affairs and recite Koran together and learn some Islamic teachings (Al-Anani 2016).

On the other hand, the process of socialisation in Al-Qaeda typically relies on the value and beliefs related to the identity of the group to be taught to the recruited member (Hartshorne 2015). Most of who are recruited in Al-Qaeda are subjected to a long process of socialisation and are expected to understand their new identity and roles into the group (Arena \& Arrigo 2006: 240). During this process, several regulations are established to shape the individual to be more susceptible to extremist (Stern, Jessica. \& Berger 2015).

Arena and Arrigo (2006), stated that Al-Qaeda does not socialise the children based on intermediate Islamic teachings, as children are not a constituent of the group. They only utilise them as a symbol for the socialisation process to obtain sympathy. However, the conditions of Al- 
Qaeda living are predominately precarious for establishing schools or institutions, as Al-Qaeda members are subject to get killed occasionally due to the precarious environment they live in. AlQaeda's failure of socialisation is due to the unstable, war-like environment they live in (Quintan, 2004). The organisation mainly only focuses on enhancing mass media not the environment, they provide millions of dollars to enhance the internet networking as it's the main platform of recruitment (Craig et al. 1994). The intriguing folks of Al-Qaeda are mostly recruited through online network, hence in 2007, Al-Qaeda produced 97 original videos in English to cajole the Western targeted audience to join the movement. Also, Al-Qaeda utilises many English foreigners with a decent English accent with to give the new recruits more confidence to join the movement (Kohlmann 2008).

\section{The Impact of Socialisation on the Muslim Brotherhood and al-Qaeda}

Many scholars argue that socialisation has a high risk of shaping a terrorist individual (Kohlmann, 2006; Lachow \& Richardson 2007; Lewis 2005). After World War II, most people would avoid arguments as much as possible. Hence, in 1950 and 1960 people extremely emphasised environmental influence on behaviour, particularly the role of families (Gould 1997). However, it seems the lesson of the past have not been studied well, where another issue instigated a vague sociological problem among scholar, which the socialisation of jihadists. Kohlmann (2006) claims that the online war on terror has been protected, concentrating on critical infrastructure. Lachow and Richardson (2007) stated that the effect of cyber terrorism should never be underestimated, neither as precious of unabated propaganda nor cyber socialisation.

Scholars have divided cyber recruitment into trinity sections: Hosted sites, non-hosted sites and online inspire magazine (Torok 2010). Hosted sites, extremist Islamist movements create websites to coax their cause as protector of Islamic beliefs against who called 'crusader' (Lewis 2005). The websites of extremist movements propagate information which are utilised to face the western ascendency view with those of their minority cause (Awan 2007 \& Lewis 2005). Several websites are created as a news platform to accentuate the concealed agenda of jihadist. Examples of these websites are jehad.net and azzam.com (McNeal 2007). A Non-hosted site, the key feature of recruitment and operational tools, relies on group chatting on social media. It is easy to transfer data files and easy to communicate with others, as it includes a felicitous venue for those who have a mutual interest to connect (Weimann 2008). Inspire magazine, a colourful cyber tool produced online beneath the name 'inspire' released in 2010. The magazine encourages people to create bombs by following instructions and details. Also, the magazine carries messages from Bin Laden endorsing the youth for joining the trajectory of Jihad (Torok 2010).

Contrary to the recruitment of Al-Qaeda, the Muslim Brotherhood recruitment is known as the fastest grown Islamic movement in the West. In 1999, it opened its first global information center in London, the press that specialised in introducing the Muslim news around the world. Moreover, it promotes perspectives of the Muslim Brotherhood which played a significant role of recruiting new members in Britain (Trauthig 2018).

In fact, the Muslim Brotherhood recruitment increases during their tribulations. In 1954, after the dissolution of the Muslim Brotherhood by Gamal Abdul Nasser, the Muslim Brotherhood members fled to Saudi Arabia where they maintained further international liaison by the year of 1980s (Vannetzel 2017). Before tribulations of the Muslim Brotherhood, particularly after the dissemination of the Muslim Brotherhood in all diameters in Egypt, Hassan Al-Banna entrenched a very intricate system for socialisation, lest the dissolution of the movement, which is name usrah family (Trager 2011).

The new members of social movements are socialised to strip their old identity marks and they are subjected to scrutiny (Smith 2008). For instance, the most significant constituent of socialisation process of the Muslim Brotherhood is usrah. This is when four individuals and one 
captain meet each week at least once and spends their time discussing their issues and Islamic teachings. After the captain confirms that all four individuals pray regularly and willing to learn the Islamic teachings, they become reckoned as muhib lover. The muhib moves up a level in the Muslim Brotherhood socialisation, when his captain in usrah confirms with the leadership that the muhib has major knowledge of Islamic teachings. This stage may take 3 years from muhib to muayyad supporter, however, the muayyad still must memorise Koran and follow duties given by his captain to move to the next step of socialisation. This is muntasib affiliated, and in this stage the muntasib will be able to work in the Muslim Brotherhood divisions, but still muntasib is not an absolute member of the Muslim Brotherhood until his captain confirms that he has studied the sayings of Prophet Muhammad and Koranic commentary to become muntazim organiser (Trager 2011). In this stage the muntasib may be tested in his peremptory toward his leadership and Muslim Brotherhood, thus if the muntasib succeeds in this stage, he will be eligible to move forward to the last stage of the Muslim Brotherhood socialisation worked brother. In this stage the individual will be allowed to participate in demonstrations and syndicates election. However, when the individual reaches the level of the worked brother, this may take longer than 10 years until the individual becomes a plenty recruited member in the Muslim Brotherhood. In the profundity of understanding the socialisation process of the Muslim Brotherhood, the movement emphasises on the individual to be a better Muslim that socialised based on Islamic teachings and Koranic commentary, thus this is the most complex system adopted within Islamic movements (Trager 2011).

Figure 1: Muslim Brotherhood Socialisation Framework

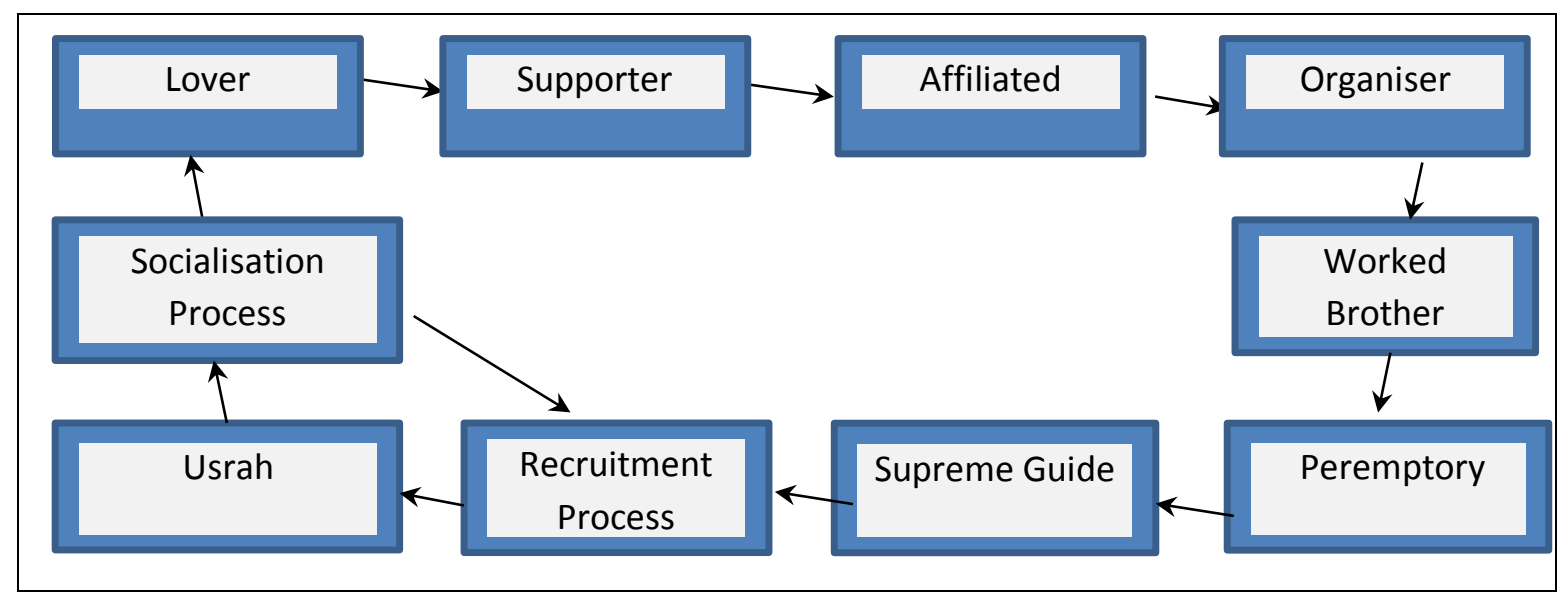

This figure explains the process of socialisation in the Muslim Brotherhood from the first step in usrah, where the individual initiates his role in the Muslim Brotherhood to being a muhib lover until he becomes a worked brother carry peremptory toward the Supreme Guide of the Muslim Brotherhood.

\section{Socialisation and Recruitment, Which One Comes First}

Recruiting Muslims for the sake of jihad has brought scholars to investigate several studies on the recruitment process of jihadist movements such as Al-Qaeda and ISIS. A few scholars have examined the link between socialisation process of those jihadist movements and recruitment, which left a gap and an unanswered question: Do jihadist movements recruit or socialise their members first?

Answering the previous question accentuates the aftermath of 11th of September, and the subsequent terrorism; extremist Islamist movements were proficient at developing their strategy of working openly without finite. Extremist Islamist movements utilised the internet technology 
as a significant platform for their imperative and operational objectives, including fundraising, recruitment and strategic direction (McNeal 2007). Also, Internet nowadays propagates extremist views that accentuated in ubiquitous on internet websites ( $O^{\prime}$ Rourke 2007). In fact, $\mathrm{Al}$ Qaeda recruitment strategies, especially segregation and isolation have instigated tension in the re-socialisation concept. In addition, most of the recruited members of Al-Qaeda had been recruited online, by utilising websites and different social media platforms. In 1998, the number of extremist Islamist movements had increased from 12 jihadi websites to 7,000 (Gunartana \& Nielsen 2008). Most importantly, the internet creates a crucial propaganda platform as a constituent of Al-Qaeda's strategy, Al-Zawahiri, the former leader of Al-Qaeda stated that 'we are in a battle, and more than half of this battleground is taking place in the battlefield of media, and we are in the media for the hearts and minds for our Muslim umma' (Michael 2009).

The propaganda of Al-Qaeda websites inveigles their target audience by telling them they have an awaiting paradise in the land of jihad. Although the censorship and hardships encountered, there are a lot of people who still find a way to join the movement. Not only AlQaeda uses social media platforms for polarisation the jihadists, but ISIS also approach their target by utilising modern techniques. For example, Jonathan Herbert, a 20 years old member of ISIS saw ISIS videos online and was zeal to join ISIS by going to Turkey, then to Syria. However, he was told that this way is no longer available and had put him on the waiting list (Warner \& Hulme 2018).

International Center for the Study of Violent Extremism estimated that ISIS recruited more than 16,000 foreigners to fight in Syria and Iraq (Anne 2016). Despite the exact number of Muslims who join extremist Islamist movements, sociologist researchers have highlighted significant question such as, why do Muslims join these extremist movements? This question introduced more questions such as, have these recruited members been socialised based on Islamic teachings? Have they come from well-to-do families?

To answer both questions, this paper will refer to case study prior to $11^{\text {th }}$ of September, when Osama Bin Laden recruited several Arabian youths to commit to his extremists plans. One of those recruited cohorts, Mohamed Atta, an Egyptian middle-aged man, has been socialised in a well-to-do family (Hooper 2001). Atta studied in Cairo University and continued his graduate studies in Germany (Ryan 2005). He was a devoted man to his religion ever since his first year in Germany. Although Atta was not raised in religious family, or graduated from religious school, but he decided to pursue Islamic knowledge and gain more understanding (Kolar 2006), this is because the majority of Egyptians that time were influenced by the Muslim Brotherhood ideology; even Atta joined the syndicates of engineering that constrained beneath the Muslim Brotherhood (Hooper 2001). But those who had been close to Atta, said that the latter has no link with the Muslim Brotherhood.

In fact, it is not necessary for the individual that came from a religious family to become an extremist person. Despite, the role of family still has a significant influence on the individual. On the other hand, Mohamed Atta has been re-socialised based on jihadist ideology, rebuffing luxury lifestyle that he lived in Egypt and Europe, to end the fate of a nation and peoples in an incident that led to serious consequences toward the Arab and Islamic nation (Shay 2004).

The issue of socialisation within Islamic movements takes a lot of time to be able to cope with the movement's strategy, and that accentuate a discrepancy in the socialisation of the individuals who been socialised in well-to-do family to become extremists. So, jihad may be the most motivation key for the individuals being extremists and seek vindictive from purposed regimes (Jongman 1988). But still accusatory to those purposed regimes are given. For instance, those Arabian regimes rebuffed the repatriation of mujahideen who fought in Afghanistan, and by neglecting the issue of repatriation, this was one of the most significant reasons for the emergence of Al Qaeda (Steinberg 2008).

Of course, socialisation is not given much attention within the extremist movements as in the Muslim Brotherhood. This is because jihadist movements focus on recruiting youth elements 
for jihad without even looking at their political and religious background, which makes it easy to penetrate these movements (Roy 2008). Contrary to jihadist movements, Hassan Al-Banna, had much focus on socialising his cohorts based on Islamic teachings, and emphasised that everyone has to go through a long process of recruitment. They need to have an immense understanding and knowledge of Islamic teachings, then they may become a complement member of the Muslim Brotherhood (Shadid 2008).

Recruitment factor plays a main role in the continuum of the jihadist movements. Even all the jihadist movements differ with each other, yet without those recruited members, the existence of jihadist movements will haemorrhage from the violent arena, and hence they focus on mobilising to increase their number without a palpable strategy in socialising them. However, socialisation function of social network needs a coherent understanding of the social culture; hence the recruited jihadists are afforded political consciousness that allows them to understand the value and salient of their incumbency (Somers \& Gibson 1993). Besides, they will need to define their interpretive frames about their given missions (McAdam \& Paulsen 1993), which are not truly inscribed within jihadists, because war and misleading are the culprits.

The misleading of these Islamist movements accentuates a significant point on the socialisation process within these leaderships. Bin Laden, who was identified amongst his followers as Imamul Muslimin "leader of Muslims" had no previous experience in Islamic sciences. Also, Institute of Study Religion and Political Geography in England examined that around 100 of jihadist leaderships had a few knowledges on Islamic sciences, despite their claim into perfection in Islamic teachings.

The targeted audience of Al-Qaeda are mostly undergraduate students, which should have better knowledge of Islamic sciences more than their leadership (Mendez 2008). Also, the disaffected and alienated students are easily seduced by Al-Qaeda recruiters (Murphy 2007). Moreover, the targeted audience of Al-Qaeda also includes diasporic communities, who are born from Muslim parents, but have not been socialised based on Islamic teachings, rather they have European passports that facilitates their movements through the world (Awan 2007). The free movements of the recruited members of Al-Qaeda brought a concern for US and European authorities (Leiken 2005; \& Michael 2009). For Al-Qaeda, recruited members from the West ease a long way of socialisation due to the lack of knowledge of those recruited who will carry peremptory toward their leadership, contrary to recruited Arabs who may have antecedent knowledge of Islamic teachings and jurisprudence. Hence, they may instigate a religious dispute among the other members, for this reason, Western jihadists are considered prized recruits (Michael 2009).

\section{Similarities and Differences in Socialisation of the Muslim Brotherhood and Al-Qaeda}

Similarities: Muslim Brotherhood and Al-Qaeda are both Islamist movements that adopt the Sunni ideology as their main credo. They are both involved in political arena, believing that Islamic teachings and politics are inseparable. Also, both had a strong objective to make a significant morph in the Muslim society, particularly by socialising the young generation in Islam.

Differences: The two movements differ in the way they communicate with their targeted audience. The way they recruit members and make them productive members of the Muslim community varies within each organisation. The Muslim Brotherhood believe in trajectory of democracy as a way of approaching political purposes, while Al-Qaeda rebuff the idea of democracy as they believe Western heresy should be fought. The Muslim Brotherhood are welcomed in various Islamic and Western countries because of their intermediate Islamic ideology, while Al-Qaeda is banned and considered as terrorist movement in most of the Islamic and Western countries. 
Since the 11th of September 2001, terrorism consideration has taken a place in North America and Europe. The West have established counterterrorism to prevent the radicalisation attacks. Yet, these attacks have not ceased, rather it has increased in London and Madrid. This concludes that the West has failed to dismantle the complex terrorist network. Furthermore, the encounter-terrorism authorities aimed to prevent radicalisation amongst Western Muslims by reaching out to Islamic scholars and organisations leaders. They detained hundreds of people involved in terrorist attacks. Policymakers preferred calling the Muslim Brotherhood for proposing their prominence in the Western Muslim Community as well as the ideological proximity to violent extremists. However, the Muslim Brotherhood played in comprehensive counterterrorism strategies, they provided programs and messages to cease the radicalisation and open the door for a new era of tolerance as well as the cooperation with the Western authorities (Vidino 2010).

To conclude, the preceding discussion has highlighted that socialisation process shapes reformist Islamist individuals and extremist Islamist individuals. The absence of family censorship, roles of schools and media can make Individuals susceptible to a radical shift from centrist to extremist. On the other hand, the Muslim Brotherhood exploits the socialisation centres to play a prominent role in the socialisation of the individual with moderate Islamic teachings. In fact, children inherit many characteristics from the family, religion, social class and self-concept (Brinkerhoff \& White 1988).

Socialisation is the process of training the individual to learn basic roles, values skills and act as appropriate to specific social groups. However, not all social groups inculcate the value of acting appropriately in the society. An extremist movement such as Al-Qaeda, has created thousands of extremists who committed several extremist attacks in the Muslim and Western society. Antithesis to Al-Qaeda, the Muslim Brotherhood, a movement that socialises its members based on Islamic teachings adopts the concept of intermediate Islamic politics to establish a Muslim community. They seek change to change wrongdoings based on Islamic teachings and reformism not extremism.

The divergence between the Muslim Brotherhood and Al-Qaeda accentuate of the differentiate methods utilised by both movements in contribution in community. The Muslim Brotherhood disseminates the ideology of intermediate Islamic concept in Europe and among Muslims, while Al-Qaeda aims to establish a coherent internet network to recruit jihadists to participate in attacking Western ideology.

\section{References}

Abdul Halim Mahmoud. 1979. Aḥdāth Șinā'āt al-Tārīkh al-Juz' al-Thānī (Incidents Made the History The second Part). Alexandaria: Dār al-Da'wah li al-Tab' wa al-Nashr.

Abdul Halim Mahmoud. 1980. Aḥdāth Sinā'āt al-Tārīkh (Incidents Made the History). Alexandaria: Dār al-Da'wah li al-Tab‘ wa al-Nahșsr.

Aboul-Enein, Y.H., 2003. Al-Ikhwan Al-Muslimeen: The Muslim Brotherhood. Military Review 83(4): 26-31.

Al-Anani, K. 2016. Inside the Muslim Brotherhood: Religion, Identity, and Politics. New York: Oxford University Press.

Al-Anani, K. 2019. Rethinking the repression-dissent nexus: assessing Egypt's Muslim Brotherhood's response to repression since the coup of 2013. Journal Democratization 26(8): 1329-1341.

Al-Qaradawi, Yusuf. 1998. Al -Ikhwan al-Muslimun 70 Aman fi al-Da 'wah wa al-Tarbiyah wa al-Jihad (Muslim Brotherhood 70 years in Advocacy, Education and Jihad). Cairo: Maktabah Wahbah.

Anne, Speckhard. 2016. ISIS defectors interviews project. International Center for the Study of Violent Extremism (ICSVE), February 29. (online) https://www.icsve.org/isis-defectorsinterviews-project-u-s-state-department-foreign-press-briefing/ [29 November 2019]. 
Arena, Michael. \& Arrigo, Bruce. 2006. The Terrorist Identity: Explaining the Terrorist Threat. New York: New York University Press.

Awan, N. 2007. Virtual jihadist media: Function, legitimacy and radicalizing efficacy. European Journal of Cultural Studies 10(3): 389-408.

Bassis, M. Gelles, J. \& Levine, A. 1998. Sociology an Introduction. 3rd ed. New York: McGraw-Hill Inc.

Benotman, Noman. \& Malik, Nikita. 2016. The Children of Islamic State. London: Quilliam.

Bergen, Peter. 2006. The Osama bin Laden I Know: An Oral History of al Qaeda's Leader. 2nd ed. New York: Free Press.

Brinkerhoff, David \& White, Lynn. 1988. Sociology. 2nd ed. Saint Paul, United States: West Publishing Company.

Brykczynski, P. 2005. Radical Islam and the nation: the relationship between religion and nationalism in the political thought of Hassan al-Banna and Sayyid Qutb. History of Intellectual Culture 5(1): 1-19.

Converse, P. E., \& Markus, G. B. 1979. Plus ca change. The new CPS Election Study Panel. American Political Science Review 2(73): 32-49.

Craig, Calhoun et al. 1994. Sociology. 6th ed. New York: McGraw Hill.

Downs, A. 1957. An Economic Theory of Political Action in a Democracy. The Journal of Political Economy. 65(2): 135-150.

Foda, Yousri. 2005. Tafgīrāt 11 Sabtambar (11 September Attacks). Al-Jazīrah, April 4. (online) https://www.aljazeera.net/programs/topsecret/2005/4/4/\%D8\%AA\%D9\%81\%D8\%AC \%D9\%8A\%D8\%B1\%D8\%A7\%D8\%AA11-\%D8\%B3\%D8\%A8\%D8\%AA\%D9\%85\%D8\%A8\%D8\%B1-\%D8\%A3\%D9\%8A\%D9\% 84\%D9\%88\%D9\%84-\%D8\%AC1 [27 November 2019].

Gomaa, Amin. 2002. Awrāq min Tārīkh al-Ikwān al-Muslimīn: Zurūf al-Nash'āt wa Shaksh al-Imām Mu'assis (Papers from the History of the Muslim Brotherhood: Conditions of Origin and the Personality of the Founding Imam). Cairo: Dār Al -Tawzī‘ wa al-Nashr al-Islamiyyah.

Gould, Stephen Jay. 1997. Dolly's Fashion and Louis's Passion. New York: American Museum of Natural History.

Gunartana, R. \& Nielsen, A. 2008. Al-Qaeda in the tribal Areas of Pakistan and beyond. Studies in Conflict \& Terrorism 31(9): 775-807.

Hartshorne, E. 2015. Al Qaeda, the Islamic State and the Terrorist Identity. A Qualitative Comparative Case-study on the Strategic Self Presented Identities of the Global Jihadist Groups. Thesis (Bachelor of Social Science). Linnaeus University, Sweden.

Henslin, James. 1995. Sociology: A Down-to-Earth Approach. 9th ed. Boston: Allyn \& Bacon.

Hess, R. D. \& Torney, J. V. 1967. The development of political attitudes in children. Chicago: Aldine Press. Canadian Journal of Political Science (Revue Canadienne de Science Politique) 1(4): 478-479.

Hoffman, Valerie. 1995. Sufism, Mystics, and Saints in Modern Egypt. Columbia: University of South Carolina Press.

Hooper, John. 2001. The shy, caring, deadly fanatic. The Guardian, September 23. (online) https://www.theguardian.com/world/2001/sep/23/september11.education November 2019].

Ibrahim, A. I. \& Alwi, E. A. Z. 2018. Pemikiran Politik Hassan Al-Banna, Syed Qutb dan Tuan Guru Nik Abdul Aziz Nik Mat: satu analisis. Asian People Journal 1(1): 214-223.

Iman, Abdul Hamid. 2005. Jam'iyyāt al-Ikhwān al-Muslimīn fi al-'Irāq, 1949-1954. (The Muslim Brotherhood Association in Iraq, 1949-1954). Mosul, Iraq: University of Mosul.

Ismail, Hamada Mahmoud. 2010. Hassan Al-Banna wa Jamāáah al-Ikhwān al-Muslimīn bayn al-Dīn wa al-Siyāsah 1949-1982. (Hassan Al-Banna and the Muslim Brotherhood between Religion and Politics 1949-1982). Amman: Dār al-Shurūq.

Jongman, Albert. 1988. Political Terrorist. 2nd ed. London: Routledge. 
Jung, Dietrich. \& Sinckair, Kirstine. 2020. Muslim Subjectivities in Global Modernity. Leiden: Brill Publishers.

Kohlmann, E. F. 2006. The real online terrorist threat. Foreign Affairs 85(5): 115-124.

Kohlmann, E. F. 2008. Al-Qa ida's "MySpace": terrorist recruitment on the internet. CTC Sentinel 1(2): 8-9.

Kolar, J. 2006. What we now know about the alleged 9-11 hijackers. Research in Political Economy 23: 3-45.

Kraemer, Gudurn. 2010. Hasan al-Banna. New York: Oneworld Publications.

Lachow, I. \& Richardson, C. 2007. Terrorist use of the internet: the real story. JFQ: Joint Force Quarterly. 45: 100-103.

Leiken, R. S. 2005. Europe's Angry Muslims. Foreign Affairs 84(4): 120-135.

Lewis, J. A. 2005. The internet and terrorism. American Society of International Law 99: 112-115.

Marsh, D. 1971. Political Socialization: The implicit assumptions questioned. British Journal of Political Science 1(4): 453-65.

McAdam, D. \& Paulsen, R. 1993. Specifying the relationship between social ties and activism. American Journal of Sociology 99 (3): 640-66.

McNeal, G. S. 2007. Cyber Embargo: Countering the Internet Jihad. Case Western Reserve University School of Law 39(3): 789-826.

Mendez, D. 2008. Facebook and Terrorism: a love hate relationship. Technobezz, n.d. (online) http://tech.blorge.com/Structure:\%20/2008/02/15/facebook-andterrorism-a-love-haterelationship-2 [12 November 2019].

Michael, G. 2009. Adam Gadahn and Al-Qaeda's Internet Strategy. Middle East Policy 16(3): 135152.

Miller, Warren \& Shanks, Merill. 1996. The New American Voter. Massachusetts: Harvard University Press.

Mokhtar, A. 2017. The Rise of the Violent Muslim Brotherhood. Hudson Institute, November 6. (online) https://www.hudson.org/research/13787-the-rise-of-the-violent-muslimbrotherhood [12 November 2019].

Munson, Z. 2001. Islamic mobilization: social movement theory and the Egyptian Muslim Brotherhood. The Sociological Quarterly 42(4): 487-510.

Murphy, C. 2007. The Internet: Midwife of Global Radicalism?: High-Tech Savvy Mushrooms from First Primitive Web Site. Science \& Spirit 18(1): 36-39.

0'Rourke, S. 2007. Virtual radicalisation: challenges for police. Proceedings of The 8th Australian Information Warfare and Security Conference. Edith Cowan University, Perth Western Australia, 3rd-4th December

Quintan, Wiktorowicz. 2004. Joining the Cause: Al-Muhajiroun and Radical Islam, The Roots of Radical Islam. CiteSeerX, n.d. (online) http://citeseerx.ist.psu.edu/viewdoc/summary?doi=10.1.1.689.7010 [19 April 2020].

Roy, 0. 2008. Al Qaeda in the West as a Youth Movement: The Power of a Narrative. Eldis, November. (online) https://www.eldis.org/document/A40891 [7th November 2019].

Ryan, J. 2005. The four p-words of militant islamist radicalization and recruitment: persecution, precedent, piety, and perseverance. Studies in Conflict \& Terrorism 30(7): 985-1011.

Sarmanlou, A. \& Goudarzi, R. 2015. Failure of Muslim Brotherhood Movement on the scene of government in Egypt and its political future. International Journal of Asian Social Science 5(7): 394-406.

Sedgwick, M. 2004. Al-Qaeda and the nature of religious terrorism. Terrorism and Political Violence 16(4): 795-814.

Shadid, K. M. 2008. The Muslim Brotherhood movement in the West Bank and Gaza. Third World Quarterly 10(2): 658-682.

Shay, Shaul. 2004. The Shahids: Islam and Suicide Attacks. United States: Transaction Publishers. 
Singer, Peter W. 2005. The new children of terror. Brookings, December 1. https://www.brookings.edu/research/the-new-children-of-terror/ [7th November 2019].

Singer, Peter W. 2003. Facing Saddam's Child Soldiers. Brookings, January 14. https://www.brookings.edu/research/facing-saddams-child-soldiers $[7$ th November 2019].

Smith, Jackie. 2008. Social Movements for Global Democracy. Michigan: The Johns Hopkins University Press.

Snider, J. 2008. Socialisation of the Islamic Terrorist: The Case of Indonesia. Thesis (Master of Arts). University of Notre Dame, Australia.

Somers, M \& Gibson, G. 1993. Reclaiming the Epistemological Other: Narrative and the Social Constitution of Identity. Ann Arbor: University of Michigan.

Steinberg, G. A. 2008. Turkish al-Qaeda: The Islamic Jihad Union and the Internationalization of Uzbek Jihadism. Strategic Insights 7(3): 1-10.

Stern, Jessica. \& Berger, J.M. 2015. ISIS: The State of Terror. New York: Ecco.

Torok, R. 2010. Make a bomb in your mums kitchen: cyber recruiting and socialisation of 'white moors' and home grown jihadists. Proceedings of the 1st Australian Counter Terrorism Conference, pp. 54-61. Secau 2010 Security Congress, Perth, 30 November 2010-2nd December 2010.

Trager, Eric. 2011. The unbreakable Muslim brotherhood, grim prospects for a liberal Egypt. Foreign Affairs, September/October. (online) https://www.foreignaffairs.com/articles/north-africa/2011-09-01/unbreakable-muslimbrotherhood [22 November 2019].

Trauthig, K. I. 2018. The Muslim Brotherhood and the West. British Journal of Middle Eastern Studies 46(2): 332-334.

Vannetzel, Marie. 2017. The Muslim Brotherhood's 'Virtuous society' and State Developmentalism in Egypt: the Politics of 'Goodness. International Development Policy: Revue internationale de politique de développement 8: 220-245.

Vidino, Lorenzo. 2010. The new Muslim Brotherhood in the West. New York: Columbia University Press.

Warner, J. \& Hulme, C. 2018. The Islamic State in Africa: Estimating Fighter Numbers in Cells Across the Continent. Combating Terrorism Center 11(7): 1-19

Weimann, G. 2008. The Psychology of Mass-Mediated Terrorism. American Behavioral Scientist 52(1): 69-86. 